January 1989

\title{
In Response: Maintenance ECT
}

Max Fink, MD

S.U.N.Y. at Stony Brook, NY

Follow this and additional works at: https://jdc.jefferson.edu/jeffjpsychiatry

Part of the Psychiatry Commons

Let us know how access to this document benefits you

\section{Recommended Citation}

Fink, MD, Max (1989) "In Response: Maintenance ECT," Jefferson Journal of Psychiatry. Vol. 7 : Iss. 1 , Article 11.

DOI: https://doi.org/10.29046/JJP.007.1.010

Available at: https://jdc.jefferson.edu/jeffjpsychiatry/vol7/iss1/11

This Article is brought to you for free and open access by the Jefferson Digital Commons. The Jefferson Digital Commons is a service of Thomas Jefferson University's Center for Teaching and Learning (CTL). The Commons is a showcase for Jefferson books and journals, peer-reviewed scholarly publications, unique historical collections from the University archives, and teaching tools. The Jefferson Digital Commons allows researchers and interested readers anywhere in the world to learn about and keep up to date with Jefferson scholarship. This article has been accepted for inclusion in Jefferson Journal of Psychiatry by an authorized administrator of the Jefferson Digital Commons. For more information, please contact: JeffersonDigitalCommons@jefferson.edu. 


\title{
In Response
}

\section{Maintenance ECT}

\author{
Max Fink, M.D.
}

Therapy resistance, relapsing illness, and rapid cycling are aspects of chronic affective illness that continue to frustrate us. ECT was re-introduced to answer the problem of therapy resistant depression. In their recent review, Matzen et al. (1), report their experience in eight cases treated with maintenance ECT. They argue that maintenance ECT should also be considered for relapsing depressive illness.

No systematic study of maintenance ECT has been undertaken since the early 1950s, and yet, as reported by Kramer (2) it continues to be used. Kramer directed inquiries to members of the International Association for the Advancement of Electrotherapy. Of 86 respondents, 51 reported they used maintenance treatments in 1986. Usage was small, however, approximately three patients per practitioner in a year. Despite the lack of experimentally derived guidelines, the procedures were relatively uniform. After an illness had responded to a course of ECT, treatments were given at weekly intervals, followed after a few weeks by bi-weekly, then monthly treatments. The treatment practice described by Matzen et al. are similar.

Two other groups, one from Duke University (3) and another from the University of Pittsburgh (4), recently reviewed their case material with maintenance ECT and found their experience salutary. In each series, the benefits of continuation ECT therapy out-weighed the disadvantages.

We need studies, however, to clarify the indications for the use of maintenance ECT, and to provide better guidelines. Abrams (5) describes the present practice in useful detail.

Prior to the 1960s, maintenance ECT was accepted practice. Compliance was difficult, however, as neither the patients nor their families appreciated the need for treatment when the patient was well. When the efficacy of tricyclic antidepressants and lithium to sustain a normal mood state was demonstrated, reports of the use of maintenance ECT disappeared from the scientific literature after 1965. The present situation is different, for patients and their families understand the need for maintenance ECT, but practitioners are reluctant to undertake the responsibility for such continuation therapy. The reluctance is increased by present complex insurance re-imbursement rules which favor hospital care and penalize out-patient and maintenance care.

Relapse is common in patients with delusional depression. These patients respond poorly to antidepressant drugs alone and are frequently referred for 
ECT. The conventional use of tricyclic antidepressant drugs or lithium for continuation therapy after the treatment of an acute episode is often insufficient to prevent relapse. Of their ECT treated patients, Aronson et al. (6) reported that $72 \%$ relapsed within one to four years. Spiker et al. (7) reported that 32 of 37 delusional depressed patients responded to a course of ECT; but in follow-up, $16(50 \%)$ relapsed within a year. Clearly, something more than the usual antidepressant drug or lithium therapies at half the therapeutic dose is needed to prevent relapse in delusional depressed patients.

Relapse is also characteristic of patients with bipolar disorder where the problem of 'rapid cycling' has been described. Some authors, notably Post and his colleagues at NIMH, augment or replace lithium therapy with the anticonvulsants carbamazepine or valproic acid. They rarely use ECT in such cases, and no trial of maintenance ECT has been reported, so we are left with anecdotal case material. The report by Matzen et al. suggests that maintenance ECT might be a useful answer to the problem of rapid cycling.

Recent interest in adrenal medullary implants and fetal grafts to the brain as treatment for severe Parkinson's Disease (PD) led me to review the literature on the use of ECT in such cases (8). There are more than 16 reports and one prospective study attesting to the efficacy of ECT in PD. The problem is one of relapse, however. It seems to me that maintenance ECT is a probable answer to the relapse in such cases, and we have urged prospective trials of ECT and maintenance ECT in PD.

Matzen et al. are to be congratulated on a fine and encouraging report.

Max Fink, M.D.

Department of Psychiatry

S.U.N.Y. at Stony Brook, New York

\section{REFERENCES}

1. Matzen TA, Martin RL, Watt TJ, Reilly DK: The use of maintenance ECT for relapsing depression. Jefferson Jrl. Psychiatry 6:52-58, 1988

2. Kramer BA: Maintenance ECT: A survey of practice (1986). Convulsive Ther $3: 260-268,1987$

3. Clarke TB, Coffey CE, Hoffman GW, Weiner RD: Continuation therapy for depression using outpatient electroconvulsive therapy. Abstracts Soc Biological Psychiatry, pg. 304, 1988

4. Thornton JE, Mulsant BH, Reynolds CF: A descriptive study of maintenance electroconvulsive therapy (M-ECT) in geriatrics. Abstracts Soc Biological Psychiatry pg. 279, 1988

5. Abrams R: Electroconvulsive Therapy. Oxford Press, New York, 1988

6. Aronson T, Shukla S, Hoff A: Continuation therapy after ECT for delusional depression: A naturalistic study of prophylactic treatments and relapse. Convulsive Ther 3:167-172, 1987

7. Spiker DG, Stein J, Rich CL: Delusional depression and electroconvulsive therapy: One year later. Convulsive Ther 1:167-172, 1985

8. Fink M: ECT for Parkinson's disease? Convulsive Ther 4:189-191, 1988 